\title{
A Study on the Incidence of Shiga Toxin Producing Escherichia coli in Dairy Cattle and Its Environment
}

\author{
K. Venkateswara Rao', A. Jagadeesh Babu' ${ }^{2}$, T. Madhava Rao ${ }^{2}$, \\ Chinta Siva Swetha ${ }^{2 *}$, P. Ramya ${ }^{4}$, Deepak $^{3}$ and S. Somasekhar ${ }^{1}$ \\ ${ }^{1}$ Department of Animal Husbandry, Andhra Pradesh, India \\ ${ }^{2}$ Department of Veterinary Public Health and Epidemiology, College of Veterinary Science, \\ Sri Venkateswara Veterinary University, Tirupati-517502, India \\ ${ }^{3}$ Department of Animal Husbandry, Karnataka, India \\ *Corresponding author
}

\section{A B S T R A C T}

\begin{tabular}{|l|}
\hline Ke y w o r d s \\
Escherichia coli, \\
$\begin{array}{l}\text { Shiga toxin, PCR, } \\
\text { Faecal samples and } \\
\text { water samples }\end{array}$ \\
\hline Article Info \\
\hline $\begin{array}{l}\text { Accepted: } \\
18 \text { October } 2018 \\
\text { Available Online: } \\
10 \text { November } 2018\end{array}$ \\
\hline \hline
\end{tabular}

The present study was designed to study the prevalence and characterization of shiga toxin producing Escherichia coli from dairy animals, water samples in dairy farms and from humans who were in close contact with animals. A total of 508 faecal samples from dairy animals, 4 water samples from dairy farms and 28 Human faecal samples, who were in close contact with animals were subjected to cultural and biochemical tests for confirmation of E. coli. The molecular characterization of positive isolates with stx1, stx2, $e a e A$ and hlyA genes and multiplex PCR for confirmation. A total 522 samples were positive for $E$. coli out of $540(96.67 \%)$ samples by culture method, $319(61.11 \%)$ positive on blood agar plate assay and various biochemical characteristics were studied. Out of 522 positive E. coli, $56(10.72 \%)$ are positive for STEC by PCR method. On multiplex PCR of stx 1 , stx 2 , eaeA and $h l y A$ genes 6 were positive 6 out of $56(8.92 \%)$. The frequent isolation of STEC strains from non human sources like animals, food and other products along with the identification of multidrug resistance and virulence genes across the Indian subcontinent poses a serious threat of the outbreaks in humans that can occur in the future.

\section{Introduction}

E. coli is an important member of the coliform group. Based on the pathogenicity and variation in biochemical characteristics, $E$. coli has been classified into 6 categories, viz. enterohaemorrhagic E. coli (EHEC), enterotoxigenic $E$. coli (ETEC), enteropathogenic $E$. coli (EPEC), enteroinvasive $\quad E$ coli (EIEC), enteroaggregative E. coli (EaggEC) and diffusely adherent E. coli (DEAC), of which the EHEC is considered as most dangerous group and also referred as shiga toxin producing E. coli (STEC). STEC is an important group of $E$. coli that can cause severe diarrhoea and responsible for a number of food borne outbreaks worldwide. The STEC family is diverse and more than 200 serotypes of STEC have been identified so far 
and more than 160 of these have been recovered from humans with haemorrhagic colitis or haemolytic uremic syndrome (Abassi $\mathrm{K}$ and Elahe T, 2015).

STEC strains produce cytotoxins known as shiga toxins (stx) which have been classified into two major classes they are shiga toxin1(stx1) and shiga toxin2(stx2) and coded by stx 1 and stx 2 genes respectively. In addition to shiga toxins, most disease-causing STEC strains produce a protein called intimin that is encoded by the eae gene and is involved in the enterocyte attaching and effacing phenotype (Bakhshi et al., 2014). Besides, a specific plasmid encoded haemolysin called EHEC haemolysin, which is encoded by ehxAgene, might contribute to the virulence of STEC for humans (Bergy et al., 1984).

Contamination of feeds such as grain pellets, soybean meal, silage grasses and grass hay with STEC may occur due to contaminated water used for cultivation of crops, spreading of manure and slurry as fertilizers or via wild birds or mammalian faeces (Brunen et al., 2004).

The ability of zoonotic STEC to survive and persist in faeces, manure and soil in the environment can be considered as a risk factor for the infection of animals and humans. It has been shown that STEC can survive for several months in water or sediment from drinking water troughs. STEC can also survive in soil for long periods particularly in the presence of manure, and during rain fall can be leached out of the soil and travel below the top layers of the soil for more than two months, increasing the probability of contamination of ground water which is recycled for crop irrigation, vegetable cleaning or as drinking water for animals and humans (Collins $\mathrm{C}$ and Green AJ, 2010).
Hence using run-off water from manure piles contaminated with zoonotic STEC as a water source for raising the fodder crops for animal grazing, silage production for animal feed or food crops for human consumption may result in persistent animal infection and a great risk of human exposure.

The first documentation of outbreak of STEC was produced by an episode involving strain O157:H7, in 1982 causing haemorrhagic colitis (HC), since then the incidence of this strain in the disease has increased annually (Dastmalchi and Ayremlou, 2012). Further, significant morbidity and mortality secondary to infection be attributed to the development of haemolytic uremic syndrome (Dhanashree and Mallya, 2008) due to STEC because of its association with several large outbreaks of human illness with severe manifestations.

Humans are infected with zoonotic STEC mostly through the consumption of under cooked hamburgers and ground beef products, raw milk and milk products such as cheese, curd, butter and ice creams. Person to person transmission via the faeco-oral route has been an important mode of transmission.

Water borne outbreaks of STEC associated with recreational waters have been increasingly reported since the early 1990's. Since, 1996 outbreaks of STEC, resulting from a new mode of transmission have been recognized i.e. direct contact between humans and cows or calves at farms and fairs etc (Duris et al., 2009).

Keeping in view of the public health significance of STEC the present study was designed to isolate and identify Escherichia coli from farm water and faeces of dairy animals and humans and molecular characterization of the isolates to find out the shiga toxin producing Escherichia coli by using specific primers. 


\section{Materials and Methods}

\section{Collection of samples}

The faecal samples from cattle, water sources of the concerned dairy farm and from the persons who are working in the farms were collected by using sterile cotton swabs for cattle, sterilized glass bottles for water samples and the persons were given sterilized plastic containers to collect their faeces. A total of 508rectal swabs from cattle, 4 water samples and 28 human faecal samples were collected aseptically in sterile normal saline tubes. The collected specimens were processed within 2 to 4 hours of collection. The source and number of samples collected in this study is given in Table 1 .

\section{Isolation and identification}

Tryptic soy broth was used for enrichment of inoculum. MacConkey agar and Eosine Methylene Blue (EMB) agar were used for isolation of Escherichia coli. Loop full of inoculum from the normal saline tubes was transferred to tryptic soy broth tubes and the tubes were incubated at $37^{\circ} \mathrm{C}$ for 24 hours. After incubation a loop full of inoculum from tryptic soy broth tubes was streaked over MacConkey agar and Eosine Methylene Blue agar plates and the plates were incubated at $37^{\circ} \mathrm{C}$ for 24 hours. Identification of the isolate was carried out by making a smear was from the growth on MacConkey agar and Eosine Methylene Blue agar plates and it was stained with Grams method of staining. Gram negative bacteria were identified up to genus level as Escherichia based on morphology. All the isolates were identified up to species level based on biochemical tests (Fagan et al., 1998). Test for haemolysis for the isolates of Escherichia coli grown over night on Eosine methylene blue agar plates were spot inoculated on tryptose soya agar plates containing $5 \%$ of disseminated sheep blood cells. The plates were incubated at $37^{\circ} \mathrm{C}$ for 24 hours and appearance of haemolytic zone around the colony was recorded. Biochemically confirmed isolates were stored in sterile Luria-Bertani glycerol broth vials and mixed well in vortex mixer. The vials were then labelled and stored for molecular characterization of the isolates.

For confirmation of Shiga Toxin producing Escherichia coli from the isolates Sorbitol Mac Conkey agar part I and Part II were used as a ready to use dehydrated media from M/s Hi-Media Laboratories, Mumbai and prepared as recommended by the manufacturer. All the isolates were streaked on Sorbitol McConkey agar plates and the plates were incubated at $37^{\circ} \mathrm{C} / 24$ hours. After incubation the plates were observed for pink colour colonies (Non O157:H7) and colour less colonies (O157:H7).

\section{Molecular characterization of isolates by multiplex PCR}

For the molecular characterization of the isolates the reference strain for Shiga toxin producing Escherichia coli MTCC 1699 was obtained from Department of Veterinary Public Health \& Epidemiology, College of Veterinary Science, Tirupati, Andhra Pradesh.

During the molecular characterization of the isolates preparation of template DNA from Escherichia coli strains was carried and isolated. The primers used in the study were custom synthesized by M/s Eurofins Genomics, Banglore (India).The details of the primers are given in Table.2.

A multiplex PCR assay was developed through synthesis of specific primers targeting stxl, stx2, eaeA and hlyA were used in our study (10) with slight modifications. After rapid DNA extraction, $5 \mu 1$ of bacterial DNA was added to a $25 \mu 1$ PCR mixture containing $50 \mathrm{mMKCl}, 20 \mathrm{mM}$ Tris- $\mathrm{HCl}$ (pH 8.4), 2.5mM 
$\mathrm{MgCl}$, $0.2 \mathrm{mM}$ each deoxynucleoside triphosphate (dATP, dUTP, dGTP, and dCTP) (Thermo, USA), $2.0 \mu$ l of each primer, and 1.0 U of TaqDNA polymerase (Thermo, USA). Amplification was performed by using a Thermal cycler (Corbett Research, Germany). Amplification was carried out at an initial denaturation of $94^{\circ} \mathrm{C}$ for 3 min followed by a cyclic denaturation at $94^{\circ} \mathrm{C}$ for 30 seconds, $55^{\circ} \mathrm{C}$ for 35 seconds and $72^{\circ} \mathrm{C}$ for $1 \mathrm{~min}$ for 35 cycles. Final extension step carried out at $72^{\circ} \mathrm{C}$ for $10 \mathrm{~min}$. On completion of the reaction, tubes with PCR products were held at $4^{\circ} \mathrm{C}$ until further analysis/confirmation.

DNA amplified by PCR was subjected to $1.5 \%$ agarose gel electrophoresis (11). About $5 \mu \mathrm{l}$ of each PCR product was mixed with $2 \mu \mathrm{l}$ of bromophenol blue (6X) loading dye and loaded into each well. Electrophoresis was performed at $5 \mathrm{v} / \mathrm{cm}$ and the motility was monitored by the migration of the dye. After sufficient migration, the gel was observed under UV trans illumination using Alpha innotech gel documentation system to visualize the bands. The PCR product size was determined by comparing with a standard low molecular weight ladder marker.

\section{Results and Discussion}

The particulars of the samples which were positive for Escherichia coli were given in Table 3 and it's characterization on cultural characteristics on blood agar and MacConkey and EMB agar.

The isolates were subjected to the biochemical tests like IMViC tests, urease test and triple sugar iron agar tests. For further confirmation of Escherichia coli, all the isolates were streaked on blood agar plates and incubated at $37^{\circ} \mathrm{C} / 24$ hours. The results revealed that 319 isolates produced $\beta$ haemolysis on blood agar plates.
For the phenotypic detection of shiga toxin producing Escherichia coli, all the Escherichia coli isolates from different sources were streaked on Sorbitol MacConkey agar plates and the plates were incubated at $37^{\circ} \mathrm{C} / 24 \mathrm{hr}$. The results revealed that none of the isolates have shown white colonies on Sorbitol MacConkey agar plates but a total of 158 isolates have shown pink colonies.

In the present study an oligonucleotide primer set was used which encodes the shiga toxins, intimin and entero haemolysins produced by the bacteria. Primers were selected on the basis of published nucleotide sequence of the $180 \mathrm{bp}$ for $s t x 1,255 \mathrm{bp}$ for $s t x 2,384 \mathrm{bp}$ for eaeAand 534 bp for $h l y A$ genes (Paton JC and Paton AW, 1998). With the desired PCR amplification of $180 \mathrm{bp}$ for stx 1, $255 \mathrm{bp}$ for stx2, 384 bp for eaeAand 534 bp for hly Agene of shiga toxin producing Escherichia coli (Figure 1).

In the present investigation, E.coli isolated from the faecal samples of cattle from the dairy farm of College of Veterinary Science, Tirupati exhibited stxl (4.34\%), stx2 (2.89\%) and $h l y A(1.44 \%)$ genes, E.coli isolates from private dairy farm 1 revealed stx 1 (8.00\%), stx2 (4.00\%) and hlyA (12.00\%) genes, whereas the E.coli isolates from private dairy farm 2 exhibited all the four genes in various combinations viz., stx $1 \quad(1.34 \%), \quad$ stx 2 (1.00\%), eaeA (1.34\%), hlyA (1.00\%), individually and a combination of stx $1+s t x 2$ $+e a e A(1.34 \%)$, and stx $1+$ stx $2+e a e A+$ $h l y A(1.34 \%)$, In the private dairy farm 3 the E.coli isolates from the faecal samples of cattle revealed stxl (3.70\%), stx2 (2.77\%), eaeA $(0.92 \%)$ and hlyA $(3.70 \%)$ genes individually and also a combination of stx $1+$ stx $2+e a e A+h l y A$ (1.85\%) genes (Fig. 1). The percentage of toxigenic genes of the isolates of Shiga Toxin producing Escherichia coli of different sources was represented in Table 4. 
From this study it is clear that pathogenesis of STEC is multifactorial and involves several virulence attributes of the organism. Rapid and sensitive methods for detection of STEC are now in force; especially there has been advance in PCR technology, which has increased the speed and has made it possible to quantitate the number of STEC organisms present in a suspected sample. These results substantiate those obtained by other methodological approaches followed by Fagan et al., 1998, who detected the shiga toxin gens (stxl and stx $x_{2}$, intimin (eaeA) gene and haemolysin $(h l y A)$ genes in animal faeces by multiplex PCR assay and reported that $19.45 \%$ samples positive for stx 1 and $6.7 \%$ samples carried stx2, $35.9 \%$ samples positive for hlyA gene and $6.7 \%$ samples positive for the eaeA genes, Jamhidi et al., (2015) observed the prevalence of shiga toxin producing $E$. coli in healthy cattle and reported that $15 \%$ isolates carried stx $1,19 \%$ possess stx 2 alone and $8 \%$ were positive for both stxl and stx2 only, Hallwell et al., (2016) detected shiga toxin genes in cattle faecal samples and reported that $85.8 \%$ positive for stxl, $60.0 \%$ carried stx2 and $52.5 \%$ were posess eaeA genes, Mahanti et al., (2013) analyzed the presence of shiga toxins by multiplex PCR and reported that $13.3 \%$ isolates carried stxl gene and $12.12 \%$ isolates positive for stx2. Sridhar et al., (2017) reported the prevalence of shiga toxins in E.coli isolates from the cattle and reported that $48.4 \%$ isolates carried stxl gene, $22.4 \%$ possess stx 2 gene, and $29.2 \%$ samples positive for the both stx 1 and stx2, Paula and Marin (2008) observed the occurrence of nonO157 STEC in dogs with diarrhoea and they reported that $7.6 \%$ isolates positive for stxl, $5.4 \%$ for stx2, $9.8 \%$ possess eaeA genesand $62 \%$ isolates carried stx 1 , stx $2, h l y A$ and eaeA genes, Islam et al., (2008) analyzed the prevalence and genetic characterization of STEC in slaughtered animals faecal samples of cattle, buffalos and goats and reported that buffalo and cattle faecal samples showed more prevalence for both stx 1 and stx 2 genes than stxl or stx2 alone, Parul et al., (2016)analyzed the STEC in cattle calves faeces samples and reported that $37.5 \%$ samples were positive for stx $1,43.75 \%$ carried stx 2 and $18.75 \%$ possess both stx 1 and stx2, $18.75 \%$ and $34.37 \%$ isolates positive for eaeA and hlyA genes. Dastmalchi and Ayremlou (2012) observed the prevalence and characterization of STEC in faeces of health and diarrhoeic calves, and reported that, $23.1 \%$ of the isolates were positive for only stx $1,26.92 \%$ isolates carried stx2 alone, $26.92 \%$ samples were positive for $e a e A$ gene and $57.69 \%$ isolates were positive for hlyA gene. Bakshi et al., (2014) observed the presence of shiga toxin genes (stxl and $s t x 2)$ and intimin (eaeA) genes in the faecal samples of calves with diarrhoea, and reported that 21 isolates were positive for the stx1, stx 2 and eaeA genes, Kumar et al., (2014) reported that among the 600 E.coli isolates, the stxl(117) gene was significantly more prevalent than stx2(53) and his study further revealed that the eaeA and the hlyA gene were significantly more prevalent in animal faecal isolates. In this study, an attempt was made to identify, isolate and characterize STEC from animals with the help of available modern method i.e. PCR. The samples were collected from different sources like organized dairy farms and local dairy units. This study showed PCR to be more sensitive to characterize STEC. The isolation of STEC was more in diarrhoeic cattle in the present study which correlated with the study of Brunen's et al., (2004) as rearing of cattle is a very common practice in Andhra Pradesh particularly in the rural areas. Again, proper hygienic practices and sanitary measures are lacking while handling of the cattle in these areas. Thus, it may be presumed that the diarrhoeic cattle's particularly can be an important source of STEC causing human enteritis. Therefore, emphasis should be given to screen the people suffering from diarrhoea for presence of STEC as a part of surveillance system. This will 
enable to reveal the actual magnitude of the problem caused by STEC and also give early warning regarding any outbreaks in future.

Four water samples from four different dairy farms were screened for E.coli in the present investigation and the results revealed that all the four samples were positive for E.coli and among them the isolates from the water source of private dairy farm 2 exhibited stx 1 and stx 2 genes. Shojaei M (2017) studied about the virulence factors of STEC in drinking water and reported that out of 200 water samples 10 were positive for STEC among these one isolate was positive for stxl, eaeA and ehlyA genes and 4 isolates were positive for stx 1 and one for stx2. Lascowki et al., (2013) reported through their investigations that Stx has been implicated as a possible pathogenic agent in drinking water responsible for gastrointestinal illness outbreaks and further in all of these cases, the presence of either stx 1 and /or st 22 genes were confirmed, but the actual amount of bacterial isolates that contained these genes in the water source was not identified. They examined 1850 water samples among these 300 were positive for $E$. coli in these 300 also only 12 isolates were positive for STEC i.e. two positive for stx 1,5 positive for stx 2 and 5 positive for both stx 1 and stx 2 at the same time no isolate was possess eaeA gene but all 12 were positive for $e h x A$ gene. Ram et al., (2007) studied about the Prevalence of multiantimicrobial-agent resistant, Shiga toxin and enterotoxin producing Escherichia coli in surface waters of river Ganga and reported that $30 \%$ of the 60 screened $E$. coli isolates from these water sources contained either stxl or stx2, Halabi et al., (2008) studied about the prevalence of Shiga toxin-, intimin- and haemolysin genes in Escherichia coli isolates from drinking water supplies in a rural area of Austria and 200 E. coli isolates were obtained from various drinking water sources and reported that only one was found to contain stx2, Ram et al., (2007) have analyzed stx gene presence in bacterial isolates obtained from water samples indicate an even higher percentage of stx gene presence in recreational waters and their results revealed that, stx genes were present in $22.7 \%$ of $E$. coli isolates obtained from the river Ganga. Duris et al., (28) have analysed stx gene presence in bacterial isolates obtained from water samples and revealed that greater than $50 \%$ of faecal coliform isolates tested positive for stx2 DNA in river water in Maryland and river water samples obtained in Michigan and Indiana. Waste water has been attributed to pollution of recreation and drinking water in specific cases (Lienemann et al., 2011) the general efflux of these to a water supply remains unknown, especially in cases where water treatment facilities are in effect. However, Walters et al., (2011) stated that attempts to relate stx gene or st $x$-producing organism presence to indicators of wastewater or faecal pollution have failed to show a correlation in many cases. This suggests that other factors besides general wastewater efflux explain the presence of microbes harbouring or expressing stx in aquatic environments. These limited studies set a wide range for which to compare stx distribution and abundance in other drinking water systems, will give information which is important to know the prevalence of stxdependent illness arising from drinking water both in animals and human beings.

In the present investigation 28 human faecal samples were screened for E.coli and 18 isolated could be identified as E.coli. Among these 18 isolates stxl, eaeA and hlyA genes were carried by one isolate, 1 isolate carried only hlyA gene and another isolate carried stx 2 and $h l y A$ genes. The findings of this study are in association with Kumar et al., (2014) isolated 11 STEC from 600 human faecal samples with bloody and mucus diarrhoea and reported that the stx 1 gene was the most common virulence gene, present in $11(100 \%)$ isolates followed by stx2 in six $(54.5 \%)$ 
isolates and further they reported that the eaeA gene was present in isolate from HUS patients only, Kumar et. al.(2014) reported that among the 600 E.coli isolates, the stx 2 gene was significantly more prevalent in animal faecal samples than in human stool isolates, and his study further revealed that the eaeA gene was present in 4 human stool isolates and the hlyA gene was significantly more prevalent in animal faecal isolates than in human stool isolates. Abassi and Elahe (2015) observed the prevalence of STEC in urine samples of patients suspected with UTI, by using multiplex PCR assay by targeting stxl and stx 2 genes and reported that 76 samples were positive for E. coli and 5 STEC strains were isolated by multiplex PCR and further reported that 5 isolates positive for stxl, 2 carried eaeA and no isolate was positive for stx2. Haugum et al., (2014) screened 12,651 stool samples of patients for a 5 years period among these 138 patient were infected with STEC in 138 positive STEC 108 isolates positive for eaeA gene, 57 isolates carried stxl, 50 possess stx 2 and 21 were positive for both stxl and stx2. Virpari et al., (2013) reported that $59 \mathrm{E}$. coli isolates that were obtained from 100 faecal samples, of which $10.16 \%$ were positive for stxl, $15.25 \%$ possess stx 2 and $5.08 \%$ were positive for eaeA gene. Sehgal et al., (2008) conducted 10 years epidemiological survey of E. coli $\mathrm{O} 157$ across India in humans and among 5678 human samples, the survey results showed that only $30(0.5 \%)$ samples were positive for E. coli O157.

Table.1 Source and number of samples collected

\begin{tabular}{|c|c|c|}
\hline S.No & Source of the sample & Number collected \\
\hline 1. & Dairy farm, College of Veterinary Science, Tirupati & 73 \\
\hline 2. & Private dairy farm 1 & 25 \\
\hline 3. & Private dairy farm 2 & 302 \\
\hline 4. & Private dairy farm 3 & 108 \\
\hline 5. & Water samples from the dairy farms & 04 \\
\hline 6. & Human faecal samples & 28 \\
\hline \multicolumn{2}{|r|}{ TOTAL } & 540 \\
\hline
\end{tabular}

Table.2 Details of oligonucleotide primers used in this study

\begin{tabular}{|c|c|c|c|c|}
\hline Primer & $\begin{array}{l}\text { Target } \\
\text { gene }\end{array}$ & $\begin{array}{l}\text { Primer sequence } \\
\left(5^{1}-3^{1}\right)\end{array}$ & $\begin{array}{l}\text { Expected amplicon } \\
\text { size(bp) }\end{array}$ & Reference \\
\hline stx 1: F & \multirow[t]{2}{*}{ stxl } & ATAAATCGCCATTCGTTGACTAC & 23 & \multirow{8}{*}{$\begin{array}{l}\text { Paton } \\
\text { and } \\
\text { paton } \\
(1998)\end{array}$} \\
\hline stx 1: $\mathrm{R}$ & & AGAACGCCCACTGAGATCATC & 21 & \\
\hline stx $2: \mathrm{F}$ & \multirow[t]{2}{*}{ stx 2} & GGCACTGTCTGAAACTGCTCC & 21 & \\
\hline stx 2: $\mathbf{R}$ & & TCGCCAGTTATCTTGACATTCTG & 22 & \\
\hline eaeA: F & \multirow[t]{2}{*}{ eaeA } & GACCCGGCACAAGCATAAGC & 20 & \\
\hline eaeA: $\mathbf{R}$ & & CCACCTGCAGCAACAAGAGG & 20 & \\
\hline$h l y A: \mathrm{F}$ & \multirow[t]{2}{*}{ hlyA } & GCATCATCAAGCGTACGTTCC & 21 & \\
\hline hlyA: R & & AATGAGCCAAGCTTGTTAAGCT & 22 & \\
\hline
\end{tabular}


Table.3 Prevalence of Escherichia coli from various sources

\begin{tabular}{|l|l|l|l|l|}
\hline S.No & Source & $\begin{array}{l}\text { No. of } \\
\text { samples } \\
\text { screened }\end{array}$ & $\begin{array}{l}\text { No. of samples } \\
\text { positive for E.coli }\end{array}$ & $\begin{array}{l}\text { No. of samples } \\
\text { positive for blood agar } \\
\text { plate test }\end{array}$ \\
\hline $\mathbf{1}$ & $\begin{array}{l}\text { Dairy farm of } \\
\text { College } \\
\text { Veterinary Science, } \\
\text { Tirupati }\end{array}$ & 73 & $69(94.52 \%)$ & $44(63.76 \%)$ \\
\hline $\mathbf{2}$ & Private dairy farm 1 & 25 & $25(100.00 \%)$ & $12(48.00 \%)$ \\
\hline $\mathbf{3}$ & Private dairy farm 2 & 302 & $298(98.67 \%)$ & $173(58.04 \%)$ \\
\hline $\mathbf{4}$ & Private dairy farm 3 & 108 & $108(100.00 \%)$ & $86(79.62 \%)$ \\
\hline $\mathbf{5}$ & Water samples & 04 & $04(100.00 \%)$ & $00(00.00 \%)$ \\
\hline $\mathbf{6 .}$ & $\begin{array}{l}\text { Human faecal } \\
\text { samples }\end{array}$ & 28 & $18(64.28 \%)$ & $04(22.22 \%)$ \\
\hline & TOTAL & 540 & $522(96.66 \%)$ & $319(61.11 \%)$ \\
\hline
\end{tabular}

Table.4 Screening and comparison of culture method for detection of Escherichia coli and multiplex PCR for detection of Shiga toxin producing E.coli

\begin{tabular}{|c|c|c|c|c|c|c|c|c|c|}
\hline \multirow{2}{*}{$\begin{array}{l}\mathrm{S} . \\
\mathrm{No}\end{array}$} & \multirow[t]{2}{*}{ Source } & \multirow{2}{*}{$\begin{array}{c}\text { No. of } \\
\text { samples } \\
\text { screened }\end{array}$} & \multirow{2}{*}{$\begin{array}{l}\text { No. of } \\
\text { E. coli } \\
\text { by } \\
\text { culture } \\
\text { method }\end{array}$} & \multicolumn{6}{|c|}{ Multiplex PCR for stxl, stx2,eaeA and hlyA genes } \\
\hline & & & & stx 1 & stx 2 & eaeA & hlyA & $\begin{array}{c}\text { stxl, stx } 2, \\
\text { eaeA }\end{array}$ & $\begin{array}{c}\text { stx } 1, \text { stx } 2, \\
e a e A \text { and } \\
h l y A\end{array}$ \\
\hline $\mathbf{1}$ & $\begin{array}{l}\text { Dairy farm } \\
\text { C.V.Sc., } \\
\text { Tirupati }\end{array}$ & 73 & 69 & $3(4.34 \%)$ & $2(2.89 \%)$ & --- & $1(1.44 \%)$ & --- & --- \\
\hline 2 & $\begin{array}{l}\text { Private dairy } \\
\text { farm } 1\end{array}$ & 25 & 25 & $2(8.00 \%)$ & $1(4.00 \%)$ & --- & $3(12.00 \%)$ & --- & --- \\
\hline 3 & $\begin{array}{l}\text { Private dairy } \\
\text { farm } 2\end{array}$ & 302 & 298 & $4(1.34 \%)$ & $3(1.00 \%)$ & $4(1.34 \%)$ & $3(1.00 \%)$ & $4(1.34 \%)$ & $4(1.34 \%)$ \\
\hline 4 & $\begin{array}{l}\text { Private dairy } \\
\text { farm } 3\end{array}$ & 108 & 108 & $4(3.70 \%)$ & $3(2.77 \%)$ & $1(0.92 \%)$ & $4(3.70 \%)$ & --- & $2(1.85 \%)$ \\
\hline 5 & Water samples & 04 & 04 & $\begin{array}{c}1 \\
(25.00 \%)\end{array}$ & $\begin{array}{c}1 \\
(25.00 \%)\end{array}$ & --- & --- & --- & --- \\
\hline 6 & $\begin{array}{c}\text { Human faecal } \\
\text { samples }\end{array}$ & 28 & 18 & $1(5.55 \%)$ & $1(5.55 \%)$ & $1(5.55 \%)$ & $\begin{array}{c}3 \\
(16.66 \%)\end{array}$ & --- & --- \\
\hline & Grand total & 540 & 522 & 15 & 11 & 6 & 14 & 4 & 6 \\
\hline
\end{tabular}


Figure.1 Detection of $S t x_{1}$, Stx2, eae and $h l y A$ genes in samples collected from cattle in different private farms

\section{$\begin{array}{lllllll}M & 1 & 2 & 3 & 4 & 5 & 6\end{array}$}

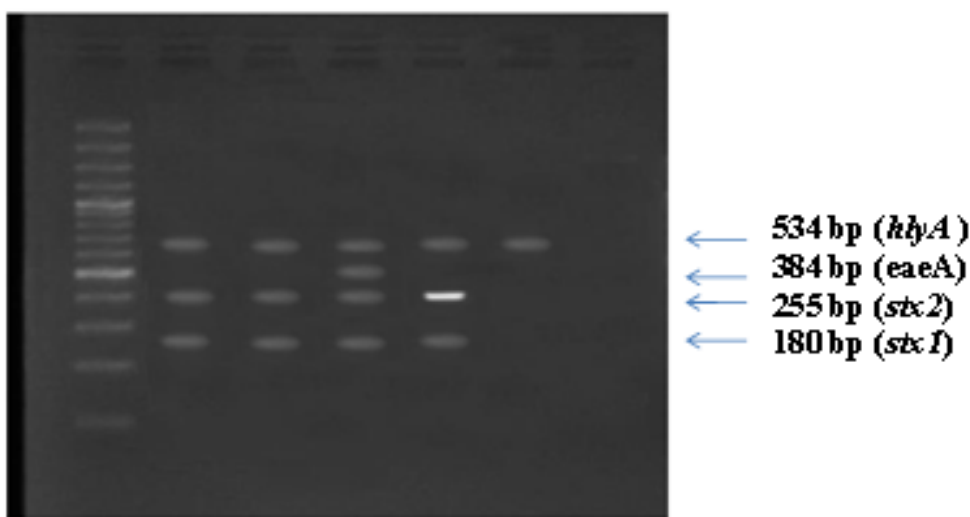

Lane: M (100 bp DNA size marker)

Lane: 1 Positive control

Lane: 2 p ositive for $s t x 1, s t x 2$, and $h b y A$

Lane: 3 positive for $s k x, s t x 2$, eaeA and $h l y A$

Lane: 4 positive for $s k x, s t x 2$, and $h h y A$

Lane: 5 positive for $h y d A$

Lane: 3 Negative control

Dhanashree and Mallya (2008) screened the diarrhoeagenic stool samples for STEC by culture methods and PCR and reported that 2 were positive for $h l y A$ and belonging to serogroup $\mathrm{O} 8$ and also 110 eaeA positive $E$. coli isolated recovered from stool samples.

In India various studies conducted have found either no or rare occurrence of STEC in humans in India. Except for diarrhoeal outbreaks (Kang, 2001), STEC does not pose a major threat to human health in India. It is not clear that why the incidence of STEC is low in India and other developing countries, despite having all the reservoirs and STEC in the food chain. Some researchers have argued that under reporting of the incidence is the cause, where as other showed that due to the presence of pre-existing stx $1, \mathrm{IgG}$ antibodies in asymptomatic cases offers positive protection against STEC infection (Karmali, 1989). But the frequent isolation of STEC strains from non human sources like animals, food and other products along with the identification of multidrug resistance and virulence genes across the Indian subcontinent poses a serious threat of the outbreaks that can occur in the future.

\section{Acknowledgement}

The authors are thankful to the Sri Venkateswara Veterinary University for providing necessary fund and facilities to do research in the Department of Veterinary Public Health and Epidemiology, College of Veterinary Science, Tirupati.

\section{References}

Abassi, K. and Elahe, T. 2015. Prevalence of Shiga toxin genes and Intimin gene in uropathogenic Escherichia coli. Journal of Coastal Life Medicine Vol. 3(10). 791-796.

Bakhshi, B., Najibi, S. and Saeed SepehriSeresht. 2014. Molecular 
Characterization of Enterohemorrhagic Escherichia coli isolates from Cattle. J Vet Med Sci76(9): 1195-1199.

Bergy, DH., Hendricks, D., Holt, SG. and Sneath, P.H. 1984. B.M. Systematic bacteriology Vol.2 Williams and Wilkins.

Brunen, SN. Carle, I. and Grimont, F. 2004. Comparison of 14 PCR systems for the detection and subtyping of stx genes in Shiga-toxin-producing Escherichia coli. Res Microbiol149:457-472.

Collins, C. and Green, AJ. 2010. Review of the pathophysiology and treatment of shiga toxin producing $E$. coli infection. Practical Gastroenterology.

Dastmalchi, S. and Ayremlou. 2012. Characterization of Shiga toxinproducing Escherichia coli (STEC) in feces of healthy and diarrheic calves in Urmia region, Iran. Iran. J. Microbol. Vol.4. 63-69.

Dhanashree, B. and Mallya, PS. 2008. Detection of shiga-toxigenic Escherichia coli (STEC) in diarrhoeagenic stool \& meat samples in Mangalore, India. Ind J Med Res 128: 271-277.

Duris, JW., Haack, SK. and Fogarty, LR. 2009. Gene and antigen markers of Shiga-toxin Producing E. coli from Michigan and Indiana river water: Occurrence and relation to recreational water quality criteria. J Environ Qual 38:1878-1886.

Fagan, KP., Michael, A., Hornitzky, Karl, A., Bettelheim and Steven P. Djordjevic. 1998. Detection of Shiga-Like Toxin (stx1 and stx2), Intimin (eaeA), and Enterohemorrhagic Escherichia coli (EHEC) Hemolysin (EHEC hlyA) Genes in Animal Faeces by Multiplex PCR. Appl Environ Microbiol 65(2): 868-872.

Fenlon, D.R. and Wilson, J. 2000. Growth of Escherichia coli $\mathrm{O} 157$ in poorly
Fermented laboratory silage: a possible environmental dimension in the epidemiology of E. coli O157. Lett. Appl. Microbiol 30 (2): 118-121.

Halabi, M., Orth, D., Grif, K., WiesholzerPittl, M., Kainz, M., Schoberl, J., Dierich, M.P., Allerberger, F. and Wurzner, R. 2008. Prevalence of Shiga toxin-, intimin- and Haemolysin genes in Escherichia coli isolates from drinking water supplies in a rural area of Austria. Int J Hyg Environ Health 211: 454-457.

Hallwell, J., Tim, R., Stanford, K., Topp, Ed. and Alexander, W. 2016. Monitoring Seven Potentially Pathogenic Escherchia coli Serogroups in a Cloed Herd of Beef Cattle from Weaning to Finishing Phases. Foodborne Pathogens and Disease Vol.13(12) 661-667.

Hassan, M., FarhadSDi, Ebrahim, R., Hossein, E., and Reza, A. 2013. Incidence of Shiga toxin-producing Escherichia coli serogroups in ruminant's meat. Meat Science 95 381388.

Haugum, K., Brandal, L.T., Lindstedt, B.A., Wester, A.L., Bergh, K. and Afset, J.E. 2014. PCR-Based Detection and Molecular Characterization of Shiga Toxin- Producing Escherichia coli Strains in a Routine Microbiology Laboratory over 16 years. Journal of Clinical Microbiology Vol. (52). 31563163.

Islam, M.A., Abdus Mondol, Enne de Boer, Rijkelt R, Beumer, Zwietering $\mathrm{MH}$, Kaisar A and Heuvelink AE.2008. Prevalence and Genetic Characterization of Shiga ToxinProducing Escherichia coli Isolates from Slaughtered Animals in Bangladesh. Appl Environ Microbiol 74(17): 5414-5421.

Jamhidi A, Rad M and Zeinali T. 2015. Detetion of Shiga toxin-producing 
Escherchia coli (STEC) in faece of healthy calves in Mashhad, Iran. Archive odRazi Institute, Vol. 0, No. 3 19-185.

Kang H. 2001. Sorbitol fermenting Shiga toxin producing Escherichia coli O157:H strains: epidemiology, phenotypic and molecular characteristics and microbiological diagnosis. J ClinMicrobiol39: 20432049.

Karmali M.A. 1989. Infection by verocytotoxin-producing Escherichia coli. Clinical Microbiological Reviews 15-38.

Kumar A, Neelam T and Meera S. 2014 An Epidemiological and Environmental Study of Shiga Toxin-Producing Escherichia coli in India. Foodborne Pathogens and Disease 11(6).

Lascowski KM, Guth BE, Martins FH, Rocha SP, Irino K and Pelayo JS. 2013. Shiga toxin-producing Escherichia coli in drinking water supplies of northparana state Brazil.JApplMirobol. Vol. 114(4).1230-1239.

Laura E, Silvana F, Alessia Z, Guerriero M, Giuliana B, Gianluca S and Stefania S. 2016. Prevalence and characteristics of verotoxigenic Escherichia coli strains isolated from pigs and pork products in Umbria and Marche regions of Italy. International Journal of Food Microbiology 232 (2016) 7-14.

Lawan MK, Mohammed B, Junaid K, Laura G, and Stefano M. 2015. Detection of Pathogenic Escherichia coli in Samples Collected at an Abattoir in Zaria, Nigeria and at Different Points in the Surrounding Environment. Int. J. Environ. Res. Public Health, Vol.12, 679-691.

Lienemann, T, Pitkanen $\mathrm{T}$, Antikainen $\mathrm{J}$, Molsa E, Miettinen I, HaukkaK,Vaara $\mathrm{M}$ and Siitonen A. 2011. Shiga toxinproducing Escherichia coli O100:H: stx (2e) in drinking water contaminated by waste water in Finland. Curr. Microbiol. 62: 1239-1244.

Mahanti A, Samanta I, Bandopaddhay S, Joardar SN, Dutta TK, Batabyal S, Sar TK and Isore DP. 2013. Isolation, molecular characterization and antibiotic resistane of Shiga Toxin producing Escherchia coli from buffalo in India. Applied Microbiology Vol.56, 291-298.

Matussek A, Ing-Marie E, Jogenfor A, Lofdahl S and Lofgren, S. 2016. Shiga toxin-producing Escherichia coli in Diarrhoeal stool of Swedish Children: Evaluation of Polymerase Chain Reaction Screening and Duration of Shiga toxin shedding. J Paediatric Infect Dis So Vol.5(2).147-151.

Nora L.P. and Analia I.E. 2014. Shiga toxin producing Escherichia coli in human,cattle, and foods.Strategies for detection and control. Frontiers in Cellular and Infection Microbiology

Parul S, Basanti B, Barkha S, Udit J and Janardan K.Y. 2016. A Study on association of virulence determinants of verotoxicEscherichia coli isolated form cattle calves. Vetworld. Vol.9. 915-918.

Paton JC and Paton A.W. 1998. Pathogenesis and diagnosis of Shiga toxin producing Escherichia coli infections. Clin Microbiol Rev 11: 450-479.

Paula C.J.S.D. and Marin J.M. 2008. Occurrence of non-O157 Shiga toxinproducing Escherichia coli in dogs with diarrhoea. Ciência Rural (38)6.

Ram S., Vajpayee P and Shanker, R. 2007. Prevalence of multi-antimicrobial-agent resistant, Shiga toxin and enterotoxin producing Escherichia coli in surface waters of river Ganga. Environ SciTechnol 41: 7383-7388.

Rasheed, M.U., Kaiser, J., Thajuddin, N., Mukesh, P., Parveez, A. and Muthukumaresan $\quad$ K.P. 2014. 
Distribution of the stx1, stx2 and hlyA genes: Antibiotic profiling in Shigatoxigenic E. coli strains isolated from food sources. Int.J.Curr.Microbiol. App.Sci 3(5): 348-361.

Sehgal R, Kumar Y and Kumar, S. 2008. Prevalence and geographical distribution of Esherichia coli $\mathrm{O} 157$ in India: a 10 -year survey. Trans $\mathrm{R}$ Soc Trop Med Hyg.,102: 380-383.

Shojaei M. 2017. Virulence Factors of ShigaToxigenic Escherichia coli in Drinking Water of Shahrekord, Iran. ejBio vol.13(1).18-21.

Sridhar, P.B., Chris, S., Lance, W.N., Xiaorong, S., Nagaraja, T.G. and Jianfa, B. 2017. Shiga Toxin Subtypes of NonO157 Escherichia coli Serogroups
Isolated from Cattle Feces. Front. Cell. Infect. Microbiol. 7:121.

Steven A.M., Gerald B. and Koudelka. 2011 Shiga toxin: Expression, distribution, and its role in the environment. Toxins 3(12):608-625.

Virpari P.K., Nayak J.B., Thaker H.C. and Brahmbhatt M.N. 2013 Isolation of pathogenic Escherichia coli from stool samples of diarrhoeal patients with history of raw milk consumption. Vet World 6(9): 659-663.

Walters, S.P., Thebo, A.L. and Boehm, A.B. 2011. Impact of urbanization and agriculture on the occurrence of bacterial pathogens and stx genes in coastal water bodies of central California. Water Res 45: 1752-1762.

\section{How to cite this article:}

Venkateswara Rao, K., A. Jagadeesh Babu, T. Madhava Rao, Chinta Siva Swetha, P. Ramya, Deepak and Somasekhar, S. 2018. A Study on the Incidence of Shiga Toxin Producing Escherichia coli in Dairy Cattle and Its Environment. Int.J.Curr.Microbiol.App.Sci. 7(11): 2461-2472. doi: https://doi.org/10.20546/ijcmas.2018.711.281 